\title{
Women's Needs Related to Family Planning: Meta-Synthesis
}

\author{
Evelyne Nascimento Pedrosa ${ }^{1}$ \\ Katia Virginia de Oliveira Feliciano ${ }^{2}$ \\ Maria Suely Medeiros Corrêa ${ }^{3}$ (iD \\ Ariani Impieri Souza ${ }^{4}$ (D)
}

'Instituto de Medicina Integral Professor Fernando Figueira, Recife, Brazil; Universidade de Pernambuco, Recife, Brazil

${ }^{2}$ Instituto de Medicina Integral Professor Fernando Figueira, Recife, Brazil

${ }^{3}$ Universidade de Pernambuco, Recife, Brazil

"Instituto de Medicina Integral Professor Fernando Figueira, Recife, Brazil; Faculdade Pernambucana de Saúde, Recife, Brazil

Email: arianiimpieri@gmail.com

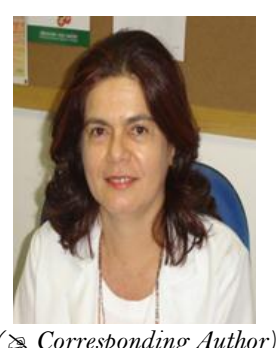

\begin{abstract}
To understand women's needs related to the care in family planning, we conducted a metasynthesis based on Noblit and Hare's meta-ethnography. Nine studies were included in this review. Five themes were identified: sociocultural access, geographical access, economic access, organizational access and quality of care. A "line of argument" synthesis was produced with six constructs: sociocultural context, accessibility, availability, functional adequacy, ability of purchasing, technical and relational adequacy. The needs relating to family planning was understood to multiple dimensions of access to health services. The most relevant aspects were: financial condition, gender and religion related as determinants of reproductive decisions; health resources inadequacy; concerns with side effects; unsatisfactory interpersonal relations; lack of information and counseling; difficulties for male access. To overcome the distance between recommended care and provided care at the services it is indispensable organization of actions committed to gender equality, considering objective and subjective aspects to the care in family planning.
\end{abstract}

Keywords: Family planning, Qualitative research, Meta-synthesis, Needs and demands of health services, Women, Women's health.

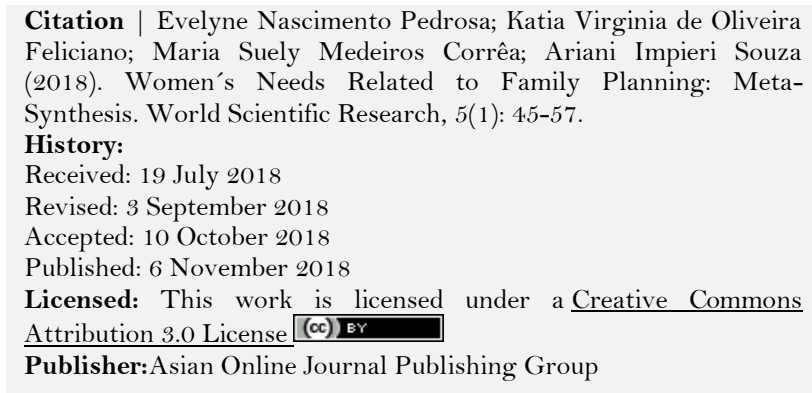

Citation | Evelyne Nascimento Pedrosa; Katia Virginia de Oliveira Feliciano; Maria Suely Medeiros Corrêa; Ariani Impieri Souza (2018). Women's Needs Related to Family Planning: MetaSynthesis. World Scientific Research, 5(1): 45-57.

History:

Received: 19 July 2018

Revised: 3 September 2018

Accepted: 10 October 2018

Published: 6 November 2018

Licensed: This work is licensed under a Creative Commons Attribution 3.0 License (c))

Publisher:Asian Online Journal Publishing Group

Contribution/Acknowledgement: All authors contributed to the conception and design of the study.

Funding: This work was funded by IMIP (Instituto de Medicina Integral Prof. Fernando Figueira) and FACEPE (Fundação de Amparo a Ciência e Tecnologia de Pernambuco) - Process number: IBPG-1306-4.01/13.

Competing Interests: The authors declare that they have no conflict of

interests.
Transparency: The authors confirm that the manuscript is an honest, Transparency: The authors confirm that the manuscript is an honest,
accurate, and transparent account of the study was reported; that no vital features of the study have been omitted; and that any discrepancies from the features of the study have been omitte
study as planned have been explained.

Ethical: This study follows all ethical practices during writing.

\section{Contents}

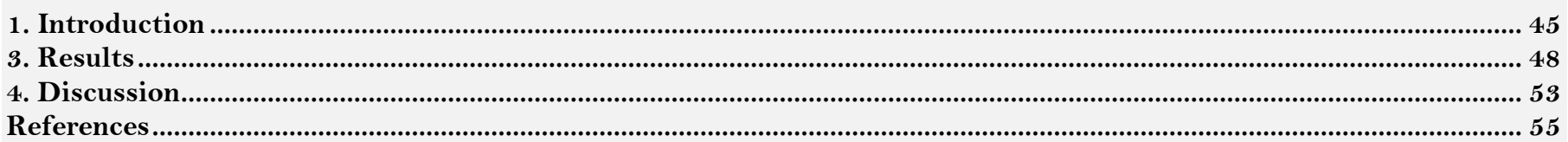




\section{Introduction}

Family planning (FP), according to World Health Organization (WHO), corresponds the right of the individual or the couple to choose freely and with responsibility of spacing pregnancies and the desired number of children, through the use of contraceptive methods and infertility treatment. WHO works to promote equitable access to FP services and the care based on technical excellence and dialog, recognizing to be essential the respect for human rights and the approach of gender relations [1].

In the world, between 1990 and 2010, the prevalence of contraception has increased and unsatisfied needs for FP declined. However, in 2015, it is estimated that 153 million women would like to space or not get pregnant, but 138 million in developing countries are not using any contraceptive methods [2]. Based on the data in 2008, WHO estimates around 22 million unsafe abortions occur per year, resulting in 47 thousand deaths and five million complications that require hospitalization, most of them occur due to contraceptive failure in FP [3].

The reduction of unsatisfied needs of FP depends on the access to the services [4, 5]. The access expresses the opportunity to obtain the services and the health actions suited to the needs perceived by the users $[6,7]$. The different perspectives of concepts of access widens the objective and subjective aspects of sociocultural, political, geographical, organizational, technical and relational dimensions of health practices [6-11].

The diversity in perception becomes essential considering the multiple perspectives to form judgments about health needs. The understanding of needs is crucial to meet professional-user in favor of more appropriate choices to concrete situations of life and also to rethink about the work process, management, planning and the construction of new knowledge and practices in health [12,13].

The objective of this synthesis was to understand women's needs related to FP care. From the range and the depth of meanings and women's experiences, it is expected to subsidize the development of actions that meet these necessities.

\section{Method}

This synthesis of qualitative studies, according to Campbell, et al. [14] used Noblit and Hare [15] metaethnographic approach, considering: a systematic review of the literature; critical quality assessment of the articles and synthesis of the results.

\subsection{A Systematic Review of the Literature}

The inclusion criteria of articles were: (a) to investigate the perspective of women aging 18 years or older on the needs related to FP; (b) original studies which exclusively used qualitative methods; (c) have been published in English, Spanish and/or Portuguese between January 2000 and December 2014 and (d) meet the quality criteria used in this study. The excluded studies were related to emergency contraception, immediate puerperium, women with HIV/AIDS, drug users and mentally ill.

The bibliographic search was done by electronic databases: PubMed/Medline, PsycINFO, CINAHL, Web of Science, LILACS and SciELO, respecting their search strategies. The descriptors were: "family planning" (OR) "family planning service" (OR) "reproductive health" (OR) "reproductive behavior" (OR) "women's health services" (AND) "perception", "attitude ", "health services needs and demand" and "qualitative research", as well as their equivalents in Portuguese and Spanish.

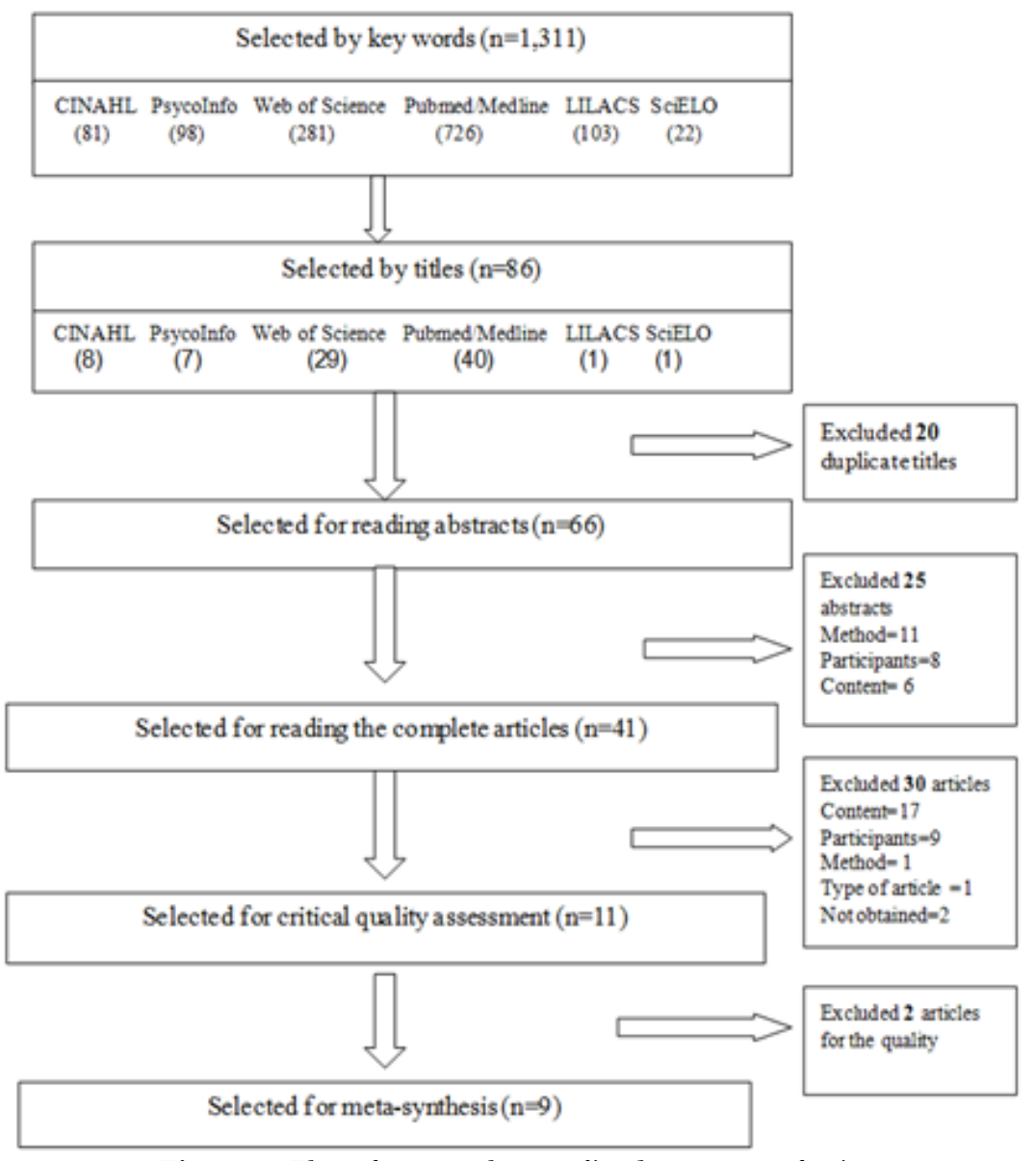

Figure-1. Flow chart to select studies for meta-synthesis Source: data prepared by authors, 2016 
Initially, 1,311 articles were identified; 86 were selected by titles, of which 20 were excluded for duplicity. Sixty-six abstracts were read, allowing 25 of them to be excluded (quantitative studies, studies with mixed quantitative predominance, age range, knowledge about contraception). So, 41 articles were read thoroughly, from those, 30 were excluded (age range, method, knowledge about contraception, sexuality and associated diseases, a presentation summary and two which did not obtain full text). At this level, 11 articles were assessed for quality. Two articles were excluded with insufficient descriptions of the results concerning the object of the study. Nine articles were selected for the final synthesis. The uncertainty and disagreements in all stages were decided by three reviewers in discussion.

Table-1. Critical quality evaluation of the studies

\begin{tabular}{|c|c|c|c|c|c|c|c|c|c|}
\hline \multirow[t]{2}{*}{ Domain/ Criteria } & \multicolumn{9}{|c|}{ Articles references } \\
\hline & [18] & {$[19]$} & {$[20]$} & {$[21]$} & [22] & {$[23]$} & [24] & [25] & [26] \\
\hline \multicolumn{10}{|l|}{ Domain 1: Research team and reflexivity } \\
\hline \multicolumn{10}{|l|}{ Personal characteristics } \\
\hline $\begin{array}{l}\text { 1. Interviewer/facilitator characteristics (Which author/s } \\
\text { conducted the research?) }\end{array}$ & - & - & $\mathrm{x}$ & - & - & - & - & $\mathrm{x}$ & - \\
\hline 2. Credential & - & - & $\mathrm{x}$ & $\mathrm{x}$ & $\mathrm{x}$ & - & - & $\mathrm{x}$ & - \\
\hline 3. Occupation & - & - & $\mathrm{x}$ & $\mathrm{x}$ & $\mathrm{x}$ & - & - & - & - \\
\hline 4. Gender & - & - & $\mathrm{x}$ & $\mathrm{x}$ & $\mathrm{x}$ & - & - & - & - \\
\hline 5. Experience and training & - & - & $\mathrm{x}$ & $\mathrm{x}$ & $\mathrm{x}$ & - & - & $\mathrm{x}$ & $\mathrm{x}$ \\
\hline \multicolumn{10}{|l|}{ Relationship with participants } \\
\hline 6. Relationship established before study commencement & - & - & - & - & - & - & - & - & - \\
\hline $\begin{array}{l}\text { 7. Participant knowledge of the interviewer (eg, personal } \\
\text { goals, reasons for doing the research) }\end{array}$ & - & - & - & - & - & - & - & - & - \\
\hline $\begin{array}{l}\text { 8. Interviewer characteristics (eg, assumptions, reasons and } \\
\text { interests in the research topics) }\end{array}$ & - & - & - & - & - & - & - & - & - \\
\hline \multicolumn{10}{|l|}{ Domain 2: Study design } \\
\hline \multicolumn{10}{|l|}{ Theoretical framework } \\
\hline 9. Methodological orientation and Theory & - & - & - & $\mathrm{x}$ & - & - & - & $\mathrm{x}$ & $\mathrm{x}$ \\
\hline 10. Social and historic context of the study & $\mathrm{x}$ & $\mathrm{x}$ & $\mathrm{x}$ & $\mathrm{x}$ & $\mathrm{x}$ & $\mathrm{X}$ & $\mathrm{x}$ & $\mathrm{x}$ & $\mathrm{x}$ \\
\hline \multicolumn{10}{|l|}{ Participant selection } \\
\hline $\begin{array}{l}\text { 11. Sampling (How were participants selected, eg, } \\
\text { purposive, convenience, and snow ball?) }\end{array}$ & - & $\mathrm{x}$ & $\mathrm{x}$ & $\mathrm{x}$ & $\mathrm{x}$ & $\mathrm{X}$ & $\mathrm{x}$ & $\mathrm{x}$ & $\mathrm{x}$ \\
\hline $\begin{array}{l}\text { 12. Method of approach (eg, face-to-face, telephone, mail, e- } \\
\text { mail) }\end{array}$ & - & $\mathrm{x}$ & $\mathrm{x}$ & $\mathrm{x}$ & $\mathrm{x}$ & $\mathrm{X}$ & - & $\mathrm{x}$ & $\mathrm{x}$ \\
\hline 13. Sample size (How many participants were in the study?) & $\mathrm{x}$ & $\mathrm{x}$ & $\mathrm{x}$ & $\mathrm{x}$ & $\mathrm{x}$ & $\mathrm{X}$ & $\mathrm{x}$ & $\mathrm{x}$ & $\mathrm{x}$ \\
\hline $\begin{array}{l}\text { 14. Nonparticipation (How many } \\
\text { participate or dropped out? Reasons?) }\end{array}$ & - & - & $\mathrm{x}$ & $\mathrm{x}$ & - & - & - & - & $\mathrm{x}$ \\
\hline \multicolumn{10}{|l|}{ Setting } \\
\hline $\begin{array}{l}\text { 15. Setting of data collection (Where were the data } \\
\text { collected?) }\end{array}$ & $\mathrm{x}$ & - & - & $\mathrm{x}$ & $\mathrm{x}$ & $\mathrm{X}$ & $\mathrm{x}$ & - & - \\
\hline $\begin{array}{l}\text { 16. Presence of nonparticipants (Was anyone else present } \\
\text { besides the participants and researchers?) }\end{array}$ & - & - & - & - & - & - & - & - & - \\
\hline $\begin{array}{l}\text { 17. Description of sample (What are the important } \\
\text { characteristics of the sample?) }\end{array}$ & $\mathrm{x}$ & $\mathrm{x}$ & $\mathrm{x}$ & - & $\mathrm{x}$ & $\mathrm{X}$ & - & $\mathrm{x}$ & $\mathrm{x}$ \\
\hline \multicolumn{10}{|l|}{ Data collection } \\
\hline $\begin{array}{l}\text { 18. Interview guide (Were questions, prompts, guides } \\
\text { provided by the authors? Was it pilot tested?) }\end{array}$ & $\mathrm{x}$ & $\mathrm{x}$ & $\mathrm{x}$ & $\mathrm{x}$ & $\mathrm{x}$ & $\mathrm{X}$ & $\mathrm{x}$ & $\mathrm{x}$ & $\mathrm{x}$ \\
\hline $\begin{array}{l}\text { 19. Repeat interviews (Were repeat interviews carried out? } \\
\text { If yes, then how many?) }\end{array}$ & na & na & na & na & - & - & - & na & - \\
\hline $\begin{array}{l}\text { 20. Audio/visual recording (Were audio or visual recording } \\
\text { used to collect the data?) }\end{array}$ & $\mathrm{x}$ & $\mathrm{x}$ & $\mathrm{x}$ & $\mathrm{x}$ & $\mathrm{x}$ & $\mathrm{X}$ & $\mathrm{x}$ & $\mathrm{x}$ & $\mathrm{x}$ \\
\hline $\begin{array}{l}\text { 21. Field notes (Were filed notes made during and/or after } \\
\text { the interview or focus group?) }\end{array}$ & - & - & $\mathrm{x}$ & $\mathrm{x}$ & - & $\mathrm{X}$ & $\mathrm{x}$ & - & - \\
\hline $\begin{array}{l}\text { 22. Duration (What was the duration of the interviews or } \\
\text { focus group?) }\end{array}$ & $\mathrm{x}$ & $\mathrm{x}$ & $\mathrm{x}$ & - & $\mathrm{x}^{(1)}$ & $\mathrm{x}^{(1)}$ & - & $\mathrm{x}$ & - \\
\hline $\begin{array}{l}\text { 23. Data (or theoretical) saturation (Was data saturation } \\
\text { discussed?) }\end{array}$ & - & - & - & - & - & $\mathrm{X}$ & $\mathrm{x}$ & $\mathrm{x}$ & $\mathrm{x}$ \\
\hline 24. Transcripts returned to participants & - & - & - & - & - & - & - & $\mathrm{x}$ & - \\
\hline 25. Ethical issues considered & $\mathrm{x}$ & $\mathrm{x}$ & $\mathrm{x}$ & $\mathrm{x}$ & $\mathrm{x}$ & $\mathrm{X}$ & $\mathrm{x}$ & $\mathrm{x}$ & $\mathrm{x}$ \\
\hline \multicolumn{10}{|l|}{ Domain 3: Analysis and findings } \\
\hline \multicolumn{10}{|l|}{ Data analysis } \\
\hline 26. Number of data coders & - & - & $\mathrm{x}$ & $\mathrm{x}$ & $\mathrm{x}$ & - & - & $\mathrm{x}$ & $\mathrm{x}$ \\
\hline 27. Description of the coding tree & $\mathrm{x}$ & $\mathrm{x}$ & $\mathrm{x}$ & $\mathrm{x}$ & $\mathrm{x}$ & $\mathrm{X}$ & $\mathrm{x}$ & $\mathrm{x}$ & $\mathrm{x}$ \\
\hline $\begin{array}{l}\text { 28. Derivation of themes (Were the themes identified in } \\
\text { advance or derived from the data?) }\end{array}$ & $\mathrm{x}$ & $\mathrm{x}$ & $\mathrm{x}$ & $\mathrm{x}$ & $\mathrm{x}$ & $\mathrm{X}$ & $\mathrm{x}$ & $\mathrm{x}$ & $\mathrm{x}$ \\
\hline $\begin{array}{l}\text { 29. Use of software (What software, if applicable, was used } \\
\text { to manage the data?) }\end{array}$ & - & - & - & - & $\mathrm{x}$ & - & - & $\mathrm{x}$ & - \\
\hline $\begin{array}{l}\text { 30. Participants checking (Did participants provide feedback } \\
\text { on the finding?) }\end{array}$ & - & - & - & - & - & - & - & $\mathrm{x}$ & - \\
\hline \multicolumn{10}{|l|}{ Reporting } \\
\hline 31. Quotations presented to illustrate the themes & $\mathrm{x}$ & $\mathrm{x}$ & $\mathrm{x}$ & - & $\mathrm{x}$ & $\mathrm{X}$ & $\mathrm{x}$ & $\mathrm{x}$ & $\mathrm{x}$ \\
\hline 32. Data and findings consistent & $\mathrm{x}$ & $\mathrm{x}$ & $\mathrm{x}$ & $\mathrm{x}$ & $\mathrm{x}$ & $\mathrm{X}$ & $\mathrm{x}$ & $\mathrm{x}$ & $\mathrm{x}$ \\
\hline 33. Clarity of major themes & $\mathrm{x}$ & $\mathrm{x}$ & $\mathrm{x}$ & $\mathrm{x}$ & $\mathrm{x}$ & $\mathrm{X}$ & $\mathrm{x}$ & $\mathrm{x}$ & $\mathrm{x}$ \\
\hline 34. Description and explanation of diverse cases & $\mathrm{x}$ & $\mathrm{x}$ & $\mathrm{x}$ & - & $\mathrm{x}$ & $\mathrm{X}$ & $\mathrm{x}$ & $\mathrm{x}$ & $\mathrm{x}$ \\
\hline
\end{tabular}

Note: na = not applicable. (1) Failed to inform the interview duration. 


\subsection{Critical Assessment of the Articles}

The summary review of the quality criteria employed an adapted version of the consolidated criteria for reporting qualitative research (COREQ) [16]. This choice was due to detail of its questionings and facilitating a more complete information exchange among the reviewers to improve the reliability of the judgments. The COREQ is composed of 32 questions into three domains: research team and reflexivity; study design and analysis and result. The adaptation corresponded to an increase in two questions about social-historical context and ethical aspects in domain [2, 17]. In the criteria analysis, all studies explained the social-historical context, guide themes, identified set of categories and inductive character of analysis [18-26]. Eight studies reported about how participants were selected [19-26]. Six mentioned type of analysis [20, 22-26] and five notified how many researchers analyzed the data [20-22, 25]. Five studies informed about researcher experience and training [20-22, 25, 26]. Three presented their theoretical-methodological foundations [21, 25, 26]. All studies did not provide any information on some criterion [18-26]. We followed the guidance by Campbell, et al. [14] and Sandelowski and Barroso [27] about the importance of performing a careful judgment to avoid the exclusion of precise and relevant studies on synthesis. Therefore, it was sought, rigorously, on the explanations and the amount of information contained in the publications [27-29]. Toye, et al. [30] alert about the necessity to consider the sufficiency of the essential aspects presentation for methodological quality. The assessment was developed by three reviewers and the results were discussed in consensus meetings.

\subsection{Synthesis of Results}

The interpretative synthesis of the results, according to Noblit and Hare [15] was obtained by reciprocal translation of articles organized chronologically: the key concepts or subthemes constituents on the themes of the first article, evidenced by thematic analysis [31] served as references and each subsequent article was compared and other articles followed. The emergence on other concepts was feedback on interpretations.

The repeated reading of each article aimed to register all present subthemes and to identify similarities and differences of the subthemes and themes within and between studies. The presence of two independent reviewers allowed to distinguish with certainty between various facets of the subthemes and to identify with greater clarity the aspects that distinguished them.

Table-2. Characteristics of primary studies included in meta-synthesis

\begin{tabular}{|c|c|c|c|c|c|c|c|}
\hline $\begin{array}{l}\text { Number } \\
\text { of } \\
\text { reference }\end{array}$ & $\begin{array}{l}\text { Authors of } \\
\text { the studies } \\
\text { / year of } \\
\text { publication }\end{array}$ & Country & $\begin{array}{l}\text { Theoretical- } \\
\text { methodological } \\
\text { approach }\end{array}$ & $\begin{array}{l}\text { Location } \\
\text { for the } \\
\text { Collection }\end{array}$ & $\begin{array}{l}\text { Research } \\
\text { technique }\end{array}$ & $\begin{array}{l}\text { Participants of the } \\
\text { study }\end{array}$ & $\begin{array}{l}\text { Type of } \\
\text { analysis }\end{array}$ \\
\hline [18] & $\begin{array}{l}\text { Ay, et al. } \\
{[18]}\end{array}$ & Turkey & - & $\begin{array}{l}\text { Participants' } \\
\text { residence }\end{array}$ & $\begin{array}{l}\text { Focal } \\
\text { group }\end{array}$ & $\begin{array}{lr}\text { Married women } \\
\text { with low } \\
\text { socioeconomic } \\
\text { stratum aged } 20-56 \\
\text { years }(\mathrm{n}=53)\end{array}$ & - \\
\hline [19] & $\begin{array}{l}\text { Khalaf, et al. } \\
\text { [19] }\end{array}$ & Jordan & - & - & $\begin{array}{l}\text { Focal } \\
\text { group }\end{array}$ & $\begin{array}{l}\text { Women aged } 18-45 \\
\text { years }(\mathrm{n}=51)\end{array}$ & - \\
\hline$[20]$ & $\begin{array}{l}\text { Mohammad- } \\
\text { Alizadeh, et } \\
\text { al. [20] }\end{array}$ & Iran & - & - & $\begin{array}{l}\text { Focal } \\
\text { group }\end{array}$ & $\begin{array}{l}\text { Married women } \\
\text { with different } \\
\text { socioeconomic } \\
\text { stratum aged } 20-49 \\
\text { years }(\mathrm{n}=53)\end{array}$ & $\begin{array}{l}\text { Content } \\
\text { Analysis } \\
\text { (Bruce L. } \\
\text { Berg) }\end{array}$ \\
\hline$\left[\begin{array}{lll}2 & 1\end{array}\right]$ & $\begin{array}{l}\text { Majlessi, et } \\
\text { al. [21] }\end{array}$ & Iran & $\begin{array}{l}\text { Grounded } \\
\text { Theory }\end{array}$ & $\begin{array}{l}\text { Primary } \\
\text { Health Care } \\
\text { Centers }\end{array}$ & $\begin{array}{l}\text { Focal } \\
\text { group }\end{array}$ & Women $(n=80)$ & - \\
\hline [22] & $\begin{array}{l}\text { Dennis and } \\
\text { Grossman } \\
{[22]}\end{array}$ & $\begin{array}{l}\text { The } \\
\text { United } \\
\text { States of } \\
\text { America }\end{array}$ & - & $\begin{array}{l}\text { Family } \\
\text { Planning } \\
\text { Clinic and } \\
\text { Researchers' } \\
\text { meeting } \\
\text { room }\end{array}$ & $\begin{array}{l}\text { Focal } \\
\text { group/ } \\
\text { Semi- } \\
\text { structured } \\
\text { interviews }\end{array}$ & $\begin{array}{l}\text { Women with low- } \\
\text { income aged 18-45 } \\
\text { years }(\mathrm{n}=45)\end{array}$ & $\begin{array}{l}\text { Thematic } \\
\text { Analysis }\end{array}$ \\
\hline [23] & $\begin{array}{l}\text { Kohan, et al. } \\
{[23]}\end{array}$ & Iran & - & $\begin{array}{l}\text { Health } \\
\text { Centers or } \\
\text { participants' } \\
\text { preference of } \\
\text { location } \\
\end{array}$ & $\begin{array}{l}\text { Focal } \\
\text { group/ } \\
\text { Semi- } \\
\text { structured } \\
\text { interviews } \\
\end{array}$ & $\begin{array}{lr}\text { Married } & \text { women } \\
\text { aged } & 20-46 \\
\text { years }(n=35) & \end{array}$ & $\begin{array}{l}\text { Content } \\
\text { Analysis } \\
\text { (Hsieh \& } \\
\text { Shannon) }\end{array}$ \\
\hline [24] & $\begin{array}{l}\text { Khan and } \\
\text { Shaikh [24] }\end{array}$ & Pakistan & - & $\begin{array}{l}\text { Union } \\
\text { Councils }\end{array}$ & $\begin{array}{l}\text { Focal } \\
\text { group/ } \\
\text { Semi- } \\
\text { structured } \\
\text { interviews }\end{array}$ & $\begin{array}{l}\text { Married women } \\
(\mathrm{n}=48) \\
\text { Professionals } \\
(\mathrm{n}=12)\end{array}$ & $\begin{array}{l}\text { Content } \\
\text { Analysis } \\
\text { (Hsieh \& } \\
\text { Shannon) }\end{array}$ \\
\hline [25] & $\begin{array}{l}\text { Hodgson, et } \\
\text { al. [25] }\end{array}$ & $\begin{array}{l}\text { The } \\
\text { United } \\
\text { States of } \\
\text { America }\end{array}$ & $\begin{array}{l}\text { Behaviorist } \\
\text { Theory }\end{array}$ & - & $\begin{array}{l}\text { Focal } \\
\text { group }\end{array}$ & $\begin{array}{l}\text { African-American } \\
\text { women with low } \\
\text { income aged 18-49 } \\
\text { years }(n=44)\end{array}$ & $\begin{array}{l}\text { Thematic } \\
\text { Analysis } \\
\text { (Bradley, } \\
\text { Curry \& } \\
\text { duties } \\
\text { deriving) }\end{array}$ \\
\hline [26] & $\begin{array}{l}\text { Kennedy, et } \\
\text { al. [26] }\end{array}$ & $\begin{array}{l}\text { The } \\
\text { United } \\
\text { States of } \\
\text { America }\end{array}$ & $\begin{array}{l}\text { Grounded } \\
\text { Theory }\end{array}$ & - & $\begin{array}{l}\text { Semi- } \\
\text { structured } \\
\text { interviews }\end{array}$ & $\begin{array}{l}\text { Homeless } \\
\text { aged } 18-45 \text { yomen } \\
(\mathrm{n}=22)\end{array}$ & $\begin{array}{l}\text { Thematic } \\
\text { Analysis }\end{array}$ \\
\hline
\end{tabular}

In this study, the notion of the first order construct was used (understanding the participants from the original studies), the second order (interpretation of understanding the participants by the authors of these studies) and the 
third order (synthesis of the first and the second order constructs in producing new theory about phenomenon) $[14,28,29]$.

Five key themes were developed from the first order constructs: sociocultural access, geographical access, economic access, organizational access and the quality of care. Besides the geographical access, which was not addressed by the authors of the articles, the primary themes coincided with the secondary. There were similarities in the interpretations of two reviewers, but the differences of the details were decided by discussion.

The synthesis produced from the first and second order constructs is being presented as a "line of arguments" constituted by six constructs of third order that are inter-related: sociocultural context, accessibility, availability, functional adequacy, ability of purchasing, technical and relational adequacy.

\section{Results}

The included studies were performed in Asia [20, 21, 23, 24] North America [22, 25, 26] Euro-Asia [18] and the Middle East [19]. Three were performed in health services [21-23] and four did not inform the collecting location $[19,20,25,26]$. The alone $[18-21,25]$ or combined focal group with semi-structured interviews [22-24] was the research technique mostly used. In eight studies the participants were women [18-23, 25, 26] and in only one there were women and professionals [24]. Mostly contained women between 18-49 years of age [19, 20, 22, $23,25,26]$ with low income $[18,20,22,25,26]$. Content analysis [20, 23, 24] and thematic analysis [22, 25, 26] were developed (Table 2 ). The primary and secondary themes identified are presented in Table 3.

Table-3. Primary and secondary themes identified in the studies

\begin{tabular}{|c|c|c|c|}
\hline THEMES & SUBTOPICS & FIRST ORDER CONSTRUCT & SECOND ORDERCONSTRUCTS \\
\hline \multirow[t]{6}{*}{$\begin{array}{l}\text { Sociocultural } \\
\text { access }\end{array}$} & $\begin{array}{l}\text { Life material } \\
\text { conditions }\end{array}$ & $\begin{array}{l}\text { Financial condition - decision on } \\
\text { pregnancy/family planning. }[19,20-24,26] \\
\text { Discontinuity - competitive demands.[26] } \\
\text { Meaning - to be homeless can be negative on } \\
\text { children.[26] Environment - lack of } \\
\text { privacy, storage.[26] }\end{array}$ & 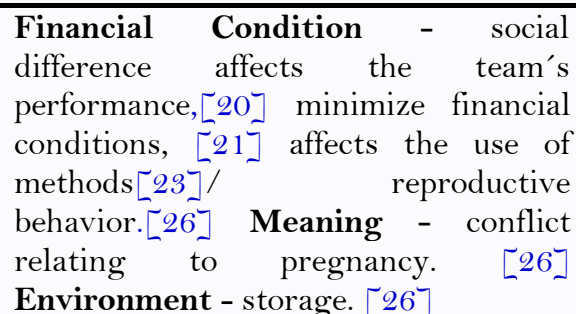 \\
\hline & Religion & $\begin{array}{l}\text { Principles - amount and spacing of } \\
\text { offsprings, [19] submission to husband, [19, } \\
23] \text { loss of peer support, pregnancy depends } \\
\text { on heavenly wish.[25] }\end{array}$ & $\begin{array}{l}\text { Religious Principles - influences } \\
\text { acceptance and the use of } \\
\text { contraception by couples, support of } \\
\text { religious leader increases the use of } \\
\text { contraception. [23] }\end{array}$ \\
\hline & $\begin{array}{l}\text { Informal } \\
\text { network } \\
\text { support }\end{array}$ & $\begin{array}{l}\text { Importance - stimulates contraception, } \\
\text { negative experiences and beliefs affect } \\
\text { choices, adults supporting adolescents, } \\
\text { schoolmates incite pregnancy. [25] } \\
\text { Communication - speak with the family, } \\
\text { good communication/silence about the } \\
\text { theme. }[25]\end{array}$ & 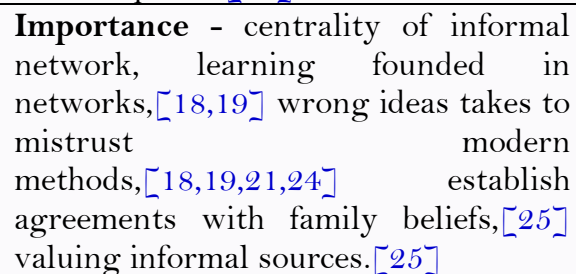 \\
\hline & $\begin{array}{l}\text { Gender } \\
\text { relations }\end{array}$ & $\begin{array}{l}\text { Offspring - have a son.[19] Partner's } \\
\text { attitude - makes the use difficult, [25,26] } \\
\text { induces not to use method,[25] } \\
\text { uncompromising, [23, 25] problems with } \\
\text { condom.[25,26] Decision - autonomy, learn } \\
\text { to decide, decision sharing, [23] concurrence } \\
\text { of partner }[19,22,23,25,26] \text { difficult } \\
\text { negotiation. [19,23,25,26] Empowerment - } \\
\text { female responsibility,[23] can decide. [22,25] }\end{array}$ & $\begin{array}{l}\text { Partner's attitude - tamper/violence } \\
\text { difficult the use of contraception.[26] } \\
\text { Decision - husband's influence } \\
{[19,20,23,25,26] \text { women's position in }} \\
\text { the family,[19] gender's equality, [20] } \\
\text { couples', decision,[23] female } \\
\text { responsibility [25,26]; Empowerment } \\
\text { - feminine autonomy affects the } \\
\text { decision, awareness of reproductive } \\
\text { rights. [23] }\end{array}$ \\
\hline & $\begin{array}{l}\text { Contraceptive } \\
\text { methods }\end{array}$ & $\begin{array}{l}\text { Effectiveness - effective pills,[22] adjust to } \\
\text { the body, side effect causes inefficiency.[25] } \\
\text { Use/gain - easy/daily use as barrier, } \\
\text { secondary benefits of the pills, [22] positive } \\
\text { on the use of IUD. [24] Drugs - rejects } \\
\text { hormonal properties, [22] unprotected } \\
\text { against STD.[22] Side effects - identifies } \\
\text { adverse consequences.[23-25] }\end{array}$ & $\begin{array}{l}\text { Disagreements - } \text { gap between } \\
\text { technical knowledge/female } \\
\text { perception, [20] know female's idea of } \\
\text { methods, } 19 \text { actions in services, [21] in } \\
\text { ethnic groups, racial/ distinct } \\
\text { socioeconomic, [25] culture affects } \\
\text { male acceptance,23 ambiguity } \\
\text { regarding pregnancy reduces efficiency } \\
{[25] \text {. }}\end{array}$ \\
\hline & $\begin{array}{l}\text { Medical } \\
\text { attention }\end{array}$ & $\begin{array}{l}\text { Reasons - first time, become pregnant after } \\
\text { suspending contraceptive, follow-up, body } \\
\text { rest, }[18] \text { adolescents and women with } \\
\text { specific health conditions. }[22,24]\end{array}$ & $\begin{array}{l}\text { Reasons - relevant concern with } \\
\text { carriers of specific health conditions. } \\
{[22]}\end{array}$ \\
\hline \multirow[t]{2}{*}{$\begin{array}{l}\text { Geographic } \\
\text { access }\end{array}$} & $\begin{array}{l}\text { Proximity of } \\
\text { the service }\end{array}$ & $\begin{array}{l}\text { Facilities - nearest public services, husband } \\
\text { does not complain. [20] }\end{array}$ & - \\
\hline & Transportation & $\begin{array}{l}\text { Facilities }- \text { depend on public } \\
\text { transportation. }[22] \text { Difficulties - lack of } \\
\text { transport, }[25,26] \text { increase the offer. }[22]\end{array}$ & - \\
\hline $\begin{array}{l}\text { Economic } \\
\text { access }\end{array}$ & Care provision & $\begin{array}{l}\text { Provider - free/low cost in the public } \\
\text { sector, [20] high cost in the private sector } \\
{[20,21]}\end{array}$ & - \\
\hline
\end{tabular}




\begin{tabular}{|c|c|c|c|}
\hline & $\begin{array}{l}\text { Contraceptive } \\
\text { methods }\end{array}$ & $\begin{array}{l}\text { Acquisition - high cost, replacement and } \\
\text { unviable concurrency of methods, acquisition } \\
\text { without prescription concerns, continue to } \\
\text { acquire by safety, commits budget, can only } \\
\text { pay what is within the budget, [22] ensure } \\
\text { free access.[24] Consultations/exams - } \\
\text { coverage reduces costs, consultations/exams } \\
\text { undertake budget, leads to planning } \\
\text { abandonment.[22] }\end{array}$ & $\begin{array}{l}\text { Acquisition - significant cost to } \\
\text { choose contraceptive/ source of } \\
\text { acquisition and discontinue use, } \\
\text { contradictory results regarding the } \\
\text { cost of purchasing without a } \\
\text { prescription for contraceptive, doubts } \\
\text { about access with free acquisition, } \\
\text { federal guidelines require full coverage } \\
\text { of insurance; [21] Access to health } \\
\text { insurance - access to health insurance } \\
\text { can improve quality of planning.[21] }\end{array}$ \\
\hline & Treatment & $\begin{array}{l}\text { Adverse effects - empowerment requires to } \\
\text { assume service costs, high healthcare costs } \\
\text { despite the free distribution costs make } \\
\text { changes on the use of method.[23] }\end{array}$ & - \\
\hline
\end{tabular}

Table-3. Primary and secondary themes identified in the studies (continued)

\begin{tabular}{|c|c|c|c|}
\hline THEMES & SUBTOPICS & FIRST ORDER CONSTRUCTS & SECOND ORDER CONSTRUCTS \\
\hline $\begin{array}{l}\text { Organizational } \\
\text { access }\end{array}$ & $\begin{array}{l}\text { Contraceptive } \\
\text { methods }\end{array}$ & $\begin{array}{l}\text { Supply - failure in the public supply } \\
\text { sector; [19] Offering - increase offer of } \\
\text { methods }[19-22,24-26] \text { wide range of } \\
\text { methods, [20, 23, 25] easy to obtain } \\
\text { condom, [22] health insurance does not } \\
\text { guarantee access; [22, 25] Periodicity - } \\
\text { adapt to women's needs, [19-22, 26] } \\
\text { inadequate dispensation, [19-22, 25, 26] } \\
\text { waste of time, [19, 20] reduce times } \\
\text { going to the service, [21, 26] health } \\
\text { insurance prevents from buying on due } \\
\text { date, [22, 25] non-bureaucratic access; } \\
\text { [26] Insufficient quantity - condoms } \\
{[19] / \text { pills; [26] Physical area - adapt }} \\
\text { for IUD; [24] Exams - more contact } \\
\text { with the services; [26] Medical } \\
\text { prescription -limited access by overload } \\
\text { professional [19]/appointment, [22] } \\
\text { prevents free acquisition of pill, free } \\
\text { acquisition would facilitate access } \\
\text { [22]/guarantee empowerment } \\
{[23] / \text { reduce the demand for exams, [22] }} \\
\text { women with specific health conditions/ } \\
\text { adolescents need medical support, more } \\
\text { side effects without medical prescription; } \\
\text { [22] Hygiene- causes fear of inserting } \\
\text { the IUD. [24] }\end{array}$ & $\begin{array}{l}\text { Supply - identify barriers; [22] } \\
\text { Offering - count on with a variety of } \\
\text { methods; [23] Periodicity -monthly } \\
\text { dispensation in public services is a } \\
\text { waste of time, [20] annual dispensation; } \\
\text { [26] Quantity - delivery of greater } \\
\text { number of pills received improves } \\
\text { adherence, greater number of pills } \\
\text { requires changes in medical } \\
\text { prescription, supply and dispensation of } \\
\text { health insurance; [22] Medical } \\
\text { prescription - reduces risk of } \\
\text { contraindication, can be seen as } \\
\text { coercion, without prescription improves } \\
\text { the use of methods, does not solve free } \\
\text { acquisition does not represent universal } \\
\text { access, presupposes informative } \\
\text { campaign on the variety of methods } \\
\text { available. [22] }\end{array}$ \\
\hline Quality of care & $\begin{array}{l}\text { Access to } \\
\text { information }\end{array}$ & $\begin{array}{l}\text { Without information - professionals do } \\
\text { not inform, }[18-22,24,25] \text { do not } \\
\text { mention about IUD, }[24,25] \text { and offer } \\
\text { only the methods they know more; }[24] \\
\text { Clarification - wish to clarify doubts; } \\
{[18,19] \text { Correction - technically }} \\
\text { appropriate, }[18-20,23,24] \text { support } \\
\text { autonomy to decide, }[23] \text { insecure about } \\
\text { information received; [18, 20]) Sources - } \\
\text { private sector informs worse [20]/best, } \\
{[21] \text { little use of written material/ }} \\
\text { audiovisual, [20] services must be } \\
\text { distributed more in printed. [20,21] }\end{array}$ & $\begin{array}{l}\text { Without information - professionals } \\
\text { do not inform; }[19,21] \text { Clarification - } \\
\text { professionals must clarify doubts, [19] } \\
\text { mental/social ability for information; } \\
{[23] \text { Correction - overcome }} \\
\text { misunderstandings }[18, \quad 19, \quad 24] \\
\text { professional informs wrong/woman } \\
\text { interprets wrongly, [18] education } \\
\text { hinders understanding, [19] women } \\
\text { want correct information, [20, 21] } \\
\text { dissatisfaction with public services; } \\
{[21] \text { Sources - authority makes }} \\
\text { professionals reliable sources. [19] }\end{array}$ \\
\hline
\end{tabular}




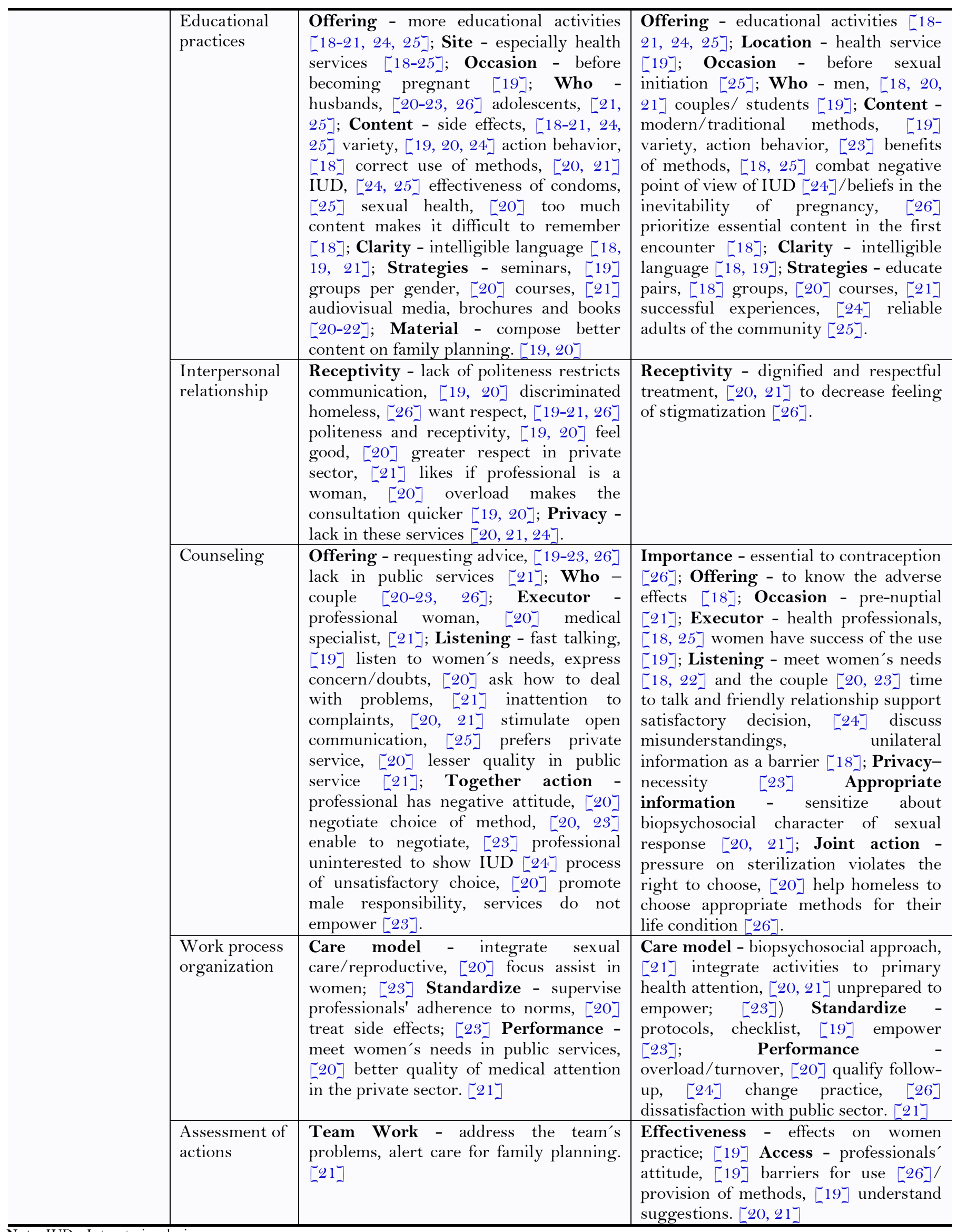

\subsection{Primary Constructs}

\subsubsection{Sociocultural Access}

In almost all the studies, the women expressed great concern about the conflict between the restrictions imposed by the material conditions of life, desire to get pregnant and the decisions in FP [19-24, 26]. They also feared the consequences of living homeless in the life of the child [26].

"I have three daughters and one son, and poverty is an important reason for not having a larger number of children" [19].

Obedience to religious principles resume the spacing of pregnancies without reducing the offspring, encouragement in having more children and the use of traditional contraceptive methods (interrupted coitus, periodic abstinence and breastfeeding) [19]. Compelled to the belief in the inevitability of pregnancy which depends on the heavenly desire [25] and unrestricted agreement with the husband [19, 23].

"All people get sleep at night except me still feeding my child. I get tired, but what to do? My husband is not allowing me to use any modern method" [19].

A study presented the informal network of support, contributing or opposing the use of contraceptive methods, owing to the experiences and beliefs prevailing in these contexts. The women mentioned about the stimulus of colleagues at school to get pregnant and the importance of adults supporting the prevention of pregnancy in 
adolescence. They would like more information on FP from the family, citing commonly the difficulties on maternal communication concerning the theme [25].

"It's hard for a lot of people to go to their parents and I was one of them because my mother did not talk about it herself." [25]

The value assigned to having a son provokes the need of new pregnancies, even among multiparous [19]. Denoted the relevance of the acquiescence of partners $[19,22,23,25,26]$ that could create obstacles: difficult negotiation $[19,23,25,26]$ disengaging [23, 25] stimulus to not use contraceptives [25] rejection and neglecting with proper handling of the condom [25, 26] and loss of its effectiveness [26].

"I did my own research and chose condoms... it took a lot of effort to persuade my husband." [23]

The female empowerment was associated with the shared responsibility in the decision and the autonomy was needed to be constructed since childhood and adolescence [23]. Few women said to have the power of decision [23, 25] although they could choose the husband's obedience [23].

"In spite the authority to decide about fertility issues on my own, I prefer to attend to my husband's will, due to family stability." [23]

In one study, the women praised the efficacy of oral contraceptives, the easily use and secondary benefits [22]. Although they felt unprotected of sexually transmitted diseases (STD) [24] some related the efficacy of the method with adequacy for the female body and ineffectiveness to side effects [25]. Effects that hinder choices [23$25]$ increased health risks [22, 23] and disapproval of the intrauterine device (IUD) [24].

\section{"Intrauterine contraceptive device (IUCD) causes infertility." [24]}

Medical attention was required to choose the method, discontinuing the use and getting pregnant after suspending the contraceptives [18]. Realizing in being able to identify the need for additional consultation, the women wanted a longer spacing [22]. The possibility to buy contraceptive without a prescription led to opine on the importance of a medical support for first time users, adolescents and patients with specific health conditions $[22,25]$.

"I think that's very dangerous for someone [with medical conditions] to be able to go get the birth control pill over the counter that could possibly harm their health. I think that it's necessary for them to go consult a doctor." [22]

\subsubsection{Geographical Access}

The proximity of public services was a facilitator to the access, because, regardless of the frequency of use, it did not please the husband [20]. Availability was mentioned in a study [22] but predominated the perception of lack of public transportation $[25,26]$ requesting to increase the offering [22].

"I don't have a car. I had to take the van and that was not there all the time." [25]

\subsubsection{Economic Access}

In public services, the assistance to $\mathrm{FP}$ was free or at low-cost [20] contrasting to the high cost in private sector [20,21]. Regardless of having a health insurance, the women need to fulfill the established family budget. The health insurance would reduce costs (consultation, exams and acquisition), but there was a fear of losing the support in buying prescribed contraceptives unless the pills were sold without a medical prescription [22].

The price of the oral contraceptive has been replaced by its use of condom and did not allow the simultaneous use of methods. The women without a health insurance could give up the FP by budget restrictions [22] and they have asked for free access to contraceptive methods [24]. For some, female empowerment requires that the services take over the costs of side effect treatments [23].

"You debate whether you get the birth control or food.... I'll forget about the birth control if it means being able to pay my rent or buying groceries." [22]

\subsubsection{Organizational Access}

The requests to increase the offering in health services at FP were common [19-22, 24, 26]. There was someone who dispose of alternatives in the public sector [19] and asked information on the offering of the services [26]. The opening hours was unsatisfactory for users who worked [20-22] and for men [20, 23]. Independently of the provider, the timetable facilitated the access for some women [22]. To host the demand of men, it was requested more flexible opening time table [20] and the extension of the working period [23].

The rejection of filling in available vacancy [20, 21] discouraged the women to return to the service [20]. And they also suggested reducing the waiting time in the public services [20] to schedule subsequent consultations, send invitation letters to attend the service and increase the workload or hire more physicians [21].

"After the long waiting time, when it is our turn, they say: 'We are completing our records. Come back another day. We have no intention of returning again." [20]

The women complained about the professionals' workload [19,20] and the employees' being slow [21] which prolonged the waiting in the services. The perception of the professional's incompetence related to FP and the side effects of the methods [20, 21] sexual health [20] placing and counseling of IUD [20, 24] generated insecurity. A high number of unpreparedness was identified in the public services [20, 21,24]. The women suggested training the professionals in the private and public services about communication with the users and IUD [20, 21, 24].

"My neighbor and I went to the same service provider/clinic in the neighborhood and she did not even mention about this method i.e. IUCD." [24]

Suggestions to improve the offering of FP to men were that the care would be performed by male professionals [22] and in adequate physical space [23]. A greater possibility of accepting the use of IUD presupposed appropriate physical space and good conditions of hygiene in the health services [24].

In one study, the women addressed the influence of lack of supply in the public services in the discontinuation of the method [19]. They also wanted to widen the range of available methods, increasing the offer of injectable 
contraceptives, IUD and condoms [20, 23, 25] mainly in public services [20]. Some received condoms easily in drugstores, gas stations, health services, etc [20]

"When I have to use contraception for 20 years, there should be several methods with few side-effects that suit my body . . so I can both avoid pregnancy and ensure I'll stay healthy." [23]

The dispensing of contraceptives was almost monthly [19-22, 25, 26] requesting to adapt periodicity in the public services for the women's needs [19-22, 26]. They also wanted to reduce the contacts with the service [21, 26] and they showed to be unsatisfied with the time spent [19, 20]. They complained about the insufficient supply of condoms [19] and pills [26]. The need for the parents' consent difficult adolescents to obtain the methods. [25] The homeless considered dispensing bureaucratic [26].

"I can't just walk up and say, "Hey, I need this [contraceptive method], I need that.' They want you to go through a process . . . but at times I be needing it at that moment." [26]

Women with health insurance, especially those who took the pills systematically, were frustrated with monthly dispensing. They suggested enlarging periodicity for authorization because the registration at the drugstores restrained contraceptives acquisition of the insurance group's deadline. The health insurance does not guarantee access to prescribed methods. [22, 25]

\section{"My insurance has limits. I can't always get birth control pills when I need." [22]}

For some women, requiring a medical prescription for dispensing methods increased the discontinuation because of the professionals' workload [19] and the difficulties in making appointments [22] limited the access of the follow-ups. The purchase of oral contraceptive without medical prescription would facilitate the access [22] and would guarantee the female empowerment [23] however, reduce the demand for the Pap smears and STD [22].

"If they didn't have to go to get a prescription, then I think they would kind a put it in the back of their mind." [22]

\subsubsection{Quality of Care}

In almost all studies, there were women that reported that they did not receive any information about contraceptive methods [18-22, 24, 25]. Two studies highlighted the silence concerning IUD [24, 25]. There was a general request in developing educational practices directed for FP in health services [18-25] schools and mosques [21]. Women [18-25] husbands [20-23, 26] and adolescents [21,25] should participate. The information was timely when offered before getting married or becoming pregnant [19].

The most concerning information were about side effects $[18-21,24,25]$ the variety and the use of methods $[19-21,24,25]$ IUD $[24,25]$ and the action of the contraceptives $[18,19]$. Some considered sufficient content which allowed them to make informed decisions [20, 25] but provide a lot of information, it was difficult to remember what was said [18]. They valued the correct information [18-20, 23, 24] which could be related to autonomy in the decision making [23]. There was a request for a wider and intelligible communication [25] with the professionals $[18,19,21]$.

"If I were given the chance to ask a doctor, and he explained modern family planning methods clearly, then I would be psychologically relaxed." [19]

Women have proposed to adopt other ways to be informed, besides oral transmission [20-22]. They requested educational practices in groups according to gender, stimulating the participation of their husbands [20] seminars [19] courses [21] and the use of audiovisual media, leaflets, booklets and books [20-22]. As they gave their opinion, the printed materials on FP needed to improve the writing [19,20] and they were important sources of information for the husbands [20].

The interpersonal relationships with the professionals were referred as unsatisfied expectations [19-21, 26]. The desire to be respected was widely expressed [19-2 1, 26] but they felt that they were not respected [20, 26]. A few realized they were more respected in the private sector [21]. Discrimination was perceived when a homeless was led to omit this information in consultation [26] and a rude treatment restricted to professional-user's communication $[19,20]$. In one study, they mentioned about being satisfied that the professional was a woman [20].

"If the health care provider treats you like that, how could you open your heart to them and talk about family planning methods?" [19]

The little time devoted to the attendance provoked criticism [19, 20]. The professionals' workload was understood as the reason for fast care [19, 20] generating misunderstandings on side effects of the methods [20]. The women complained about the lack of privacy in the health services: more than one professional in the same room [20] students in the consultation [21] jeopardizing the placement of IUD [24].

"First, providers should listen to women and then make the recommendation... But they don't listen to what we say and judge too quickly." [20]

The women asked for individual counseling [19-21, 23, 26] and for the couple [20-23, 26] about contraceptive methods [19-21, 23, 26] and sexual health [20]. Highlighting the need to support those with greater difficulty of negotiation [20] and the men's responsibility is on the contraception [23]. The counseling should be performed by an expert physician [21] or a professional woman [20]. They did not like the fast talking [19] and inattention of the professionals regarding to the complaints about side effects [20, 21]. 
The wishes to be heard and to express their concerns and doubts about FP [21] and the choice of the method [20] were present. A minority of them proposed that the professionals negotiated the choice of the method [20, 23] without imperative attitudes [20]. They affirmed that the freedom of choice was ignored [20, 23] and they would like to have a focused assistance for their necessities [23].

"I requested the injectable. She [the provider] shouted at me and said: 'I have told you to go for tubal ligation' I have been getting the injectable from the private midwifery clinic." [20]

A few women related the qualified care and the availability of trained professionals to discuss the methods. Despite being a right, the health services were not in favor of the women's empowerment [23]. They would like to participate of the decision along with the husbands [20, 22, 23, 26].

"I think if my husband can accompany me to the counseling session at the health center, he will be more supportive in the contraception use."[23]

For some women, the public services were more satisfying to the women's needs of FP [20] for others, the medical care at the private sector was better [21]. A few women mentioned on the lack of integrality in the sexual care and reproductive health [20]. For work organization, it was suggested to supervise the professionals' adherence to the norms [20], establish side effect treatments [23] and monitor actions, addressing the problems with the team to have a better attitude towards the users [21].

\subsection{Secondary Constructs}

Subthemes as costs for healthcare and side effect treatments were absent from the secondary interpretations. The authors of the studies have pointed out the widespread ideas in informal support networks, [18, 19, 21, 24, 25] requiring to combat misunderstandings $[18,24-26]$ or establish agreements between technical knowledge and common sense, $[21,25]$ as well as in gender relations, the influence of the husbands in the decisions [19, 20, 23, $25,26]$ and the women's perception in the responsibility of FP $[25,26]$. To expand the women's awareness of their rights, their empowerment affected their reproductive decisions. [23]

Also, proposed to increase the offering of health services with FP, [20, 21, 23, 24, 26] develop educational practices $[18-21,24,25]$ and counseling in services, [18-24, 26] with male participation. [18-21, 24, 25] The professionals needed training in: sexual and reproductive health, [20, 21] IUD procedure, [24] counseling [21, 24] and communicative practices. [19,24] The unilateral communication represented a barrier $[18,25]$ and the pressure for sterilization infringed the right to choose [26]. The homeless women needed specific care strategies[26].

\section{Discussion}

The issues relating to women's needs in FP understood the multiple dimensions to health services access. Its most relevant aspects were financial conditions, [19-24, 26] gender relations [19, 22, 23, 25, 26] and religion [19, $22,23,25]$ as determinants of reproductive decisions, concerns with side effects, [18-24] inadequacy in health resources, [19-26] shortage of information and counseling [18-26] and dissatisfaction with interpersonal relations. [19-2 1, 26] The public sector was perceived as the most deficit [19-22, 24, 26]. The reference in lack of transportation [22, 25, 26] and health insurance [22, 25] occurred only in the United States.

Some interpretations of second order presented differences in the perspectives relating to women. The predominance of a negative view in the influence of the informal network in the use of contraceptive methods was identified $[18,19,21,24,25]$. The educational practices should be directed to overcome misunderstandings relating to side effects, $[18,25]$ IUD [24] and inevitability of getting pregnant [26]. The ambiguous attitudes concerning pregnancy reduced the effective use of contraceptives [19]. The social differences between professionals and users affected the team's performance [20].

The "line of arguments" developed was allowed to reflect on the ability to perceive the needs, obtain care and commit to FP recommendations. The model goes from the sociocultural dimension to the technical-relational assuming that various dimensions interpenetrated.

The sociocultural context closes the material and cultural conditions of the production, transmission and reception of symbolic forms (words, actions and meaningful objects) which controls the relationships and the opportunities of access [7]. In this study, the lack of material goods [19-24, 26] and social recognition [26] to raise children properly, in certain circumstances, stimulating the prevention of pregnancy in detriment the desire of the couples. With other women, religious precepts to increase offspring were accepted as inevitable, [19, 22, 23, 25] regardless of their financial conditions. Religious leaders have a remarkable influence on the size of the families, promoting only natural methods, supporting or prohibiting FP [32-34].

Religious principles have reinforced on men's dominance in reproductive decisions [19, 23]. The rare appreciation of the women's domain in the decision[23, 25] was an attempt to avoid conflicts. However, most of the women are tensioned by diverging demands and wish that both have space and voice with FP [20-23, 26]. Strongly understanding polarized gender characterizes of patriarchal contexts [33-35]. In extreme situations, the woman keeps secret of the use of the method [32]. It is noted that there is a relationship between unsatisfied needs with FP and the lack of communication of the couples $[32,34,36]$. The communication may be limited even when men approve FP [34].

The fragile decision power of the woman denotes the ambiguous features of autonomy and the female responsibility. Ambiguity is nourished by the difficulty to talk, $[16,17,32,36]$ inaccurate understanding of the partners' opinions and the fear of a retaliation of the disagreements [34]. The use of condom [34] and the side effects that reduce sexual pleasure affect the marital relations [32, 34]. The contraception can be associated with promiscuity and infidelity $[34,36,37]$. 
Literature shows, as in this research,[18-25] the fear of side effects inhibits the acceptance of modern contraceptive methods [32,34, 36-38]. The infertility is one of the greatest fears [37, 38]. Even when women have multiple sources of information, the greatest sharing of meanings among participants facilitates the influence of informal support networks [32, 37, 38]. Although they could encourage or discourage the use of contraceptives, [37] the professionals tend to blame the networks for unjustified ideas relating to side effects, causing resistance to the methods $[18,19,21,24,25]$. The pretense to combat the misunderstandings jeopardizes the dialog and reinforcing the unilateral informative communication that can strengthen the resistance to technical content [39].

The appreciation of the authority in medical knowledge has become a required consultation, mainly, to choose the appropriate method and understand the intercurrences. In the contexts of restrictions in offering consultation and minimum counseling, as in the current study, [19-24, 26] many women interrupt the use of the method when the side effects persist, instead of having medical consultation [32]. There are those who prefer to dispense professional assistance to use a method [40].

The accessibility denotes the relationship between the location of the services and the users, the distance between them, the form of dislocation and the offering of transportation $[6,8,10]$. Decentralizing the assistance is fundamental to improve accessibility to the care, seeking to ensure a spatial distribution which facilitates the use of resources by the users [9]. The gender relations influence personal mobility, with the husbands preventing the use of distant health services [33]. The lack of transportation and the long waiting hours to arrive at the service makes it difficult to have access to FP. [32]

The availability indicates the existence of health resources with sufficient capacity to pay the necessary attention at appropriate time $[6,8,10]$. The limitations in the offering of resources to FP were widely reported [19-26]. Similar to other results, [4, 5, 32,33] insufficient number of health services, professionals and vacancies for consultation, small offering for IUD, few alternatives to choose and restrictive criteria of dispensing methods was found. There is no reference of offering vasectomy. Health resources for FP can still be scarcer in rural areas and small villages [33].

The functional adequacy reveals the perception by the user of the convenience of the organization of offering services and actions $[6,8]$. The general dissatisfaction with the existing resources evidences the lack of conformity to access FP [18-26]. The predominance of low income women may be the reason for the greater discontent with the public sector. Other studies show the desire of availability of greater variety of methods [5] and the preference for private health services [33]. The inadequacy, also, present in the demands of health resources perceived as facilitators to access men to $\mathrm{FP}[20,22,23]$. The professional's gender is also appreciated in another research [33].

The ability to purchase corresponds the availability of resources to pay the necessary care (consultations, procedures, exams and medicines) and transportation [6, 8, 9]. In other studies, [9, 33] the economic restrictions led to suppress the use or discontinue the use, [22] even when the benefits were recognized. The partners' responsibility with the cost with FP can inhibit access to the services and influence the use of contraceptive methods [33, 35]. They complain about the impact of the cost with the side effect treatment in the family budget [34]. An important barrier to access, [32,33] the transportation costs were not mentioned. The woman has more empowerment with FP when she has her own income [9].

The technical and relational adequacy expresses the conformity between services and users as for the technical quality, interpersonal relationship and communication $[6,8]$. In this study, there was no reference to anamnesis and physical examination, fundamental instruments to assess specific conditions, identifying problems, indicating appropriate contraceptive methods and performing follow-ups of women. An inadequate clinical approach is unfeasible to a care with FP based on scientific evidence [1].

The low receptivity and discourtesy restricted professional-user communication, [19-21, 26] inclusively, leading to hide the homeless woman's condition [26]. The paternalistic model of communication predominates, in which the woman is little informed and almost does not participate in decisions concerning the method [39]. In a systematic review, the low-income users have less emotional support, limited conversation to the interest of the professional and a small participation in the decisions [41]. When the impersonality departs from the individuals of their emotions, desires and principles, the precedence in technical knowledge distances from the subjects.[39] Recognizing the user as the interlocutor is fundamental to build a bond of trust with the professional, favoring the co-responsibility. [12]

The limitations in educational practices and counseling reinforce the perception that FP does not offer an effective contribution to informed decision [42] and gender relations [43]. Women have recognized as fundamental the commitment of the partner in the contraception [20-23, 26]. However, commonly, the services minimize the fact that the professional support to the negotiation of the method by the couple assumes the receptiveness to the man's needs $[36,37]$. Note that it is essential to reframe the current understanding among men to be the primary decision makers on FP and remain independent of reproductive health issues.[34]

In this synthesis, the women expressed distinct and similar perspectives on various dimensions to access FP, evidencing the gap between the recommendations of WHO and the reality of the services. To achieve greater reciprocity between needs and opportunities to access, it is essential an organization of actions committed in the mediation of the equality of gender, contemplating the objective and subjective aspects of care with FP. Although not mentioned, the infertility-related needs should be investigated and satisfied within the FP.

In the application of the results in this review, we should consider: first, regardless of sociocultural diversity of countries included in the synthesis, the differences among them were related mainly to transportation and health insurance' availability in the United States. Second, most of the studies were carried out in Islamic countries, which can, on the one hand, become more critical the inequalities in gender relations and, on the other hand, closer understanding of the FP needs. Thirdly, most of the women had a low-income, enabling to a greater use of the public health services. Fourthly, the characteristics of the health systems, certainly, influenced the participants' experiences. However, despite the diversity of contexts, a network of information was built to provide greater understanding of this phenomenon. 


\section{References}

[1] World Health Organization, Ensuring human rights within contraceptive service delivery: Implementation guide. From UNFPA (United Nations Population Fund) and WHO (World Health Organization), 2015. Available from http://apps.who.int/iris/bitstream/10665/158866/1/9789241549103_eng.pdf?ua=1, 2015 .

[2] L. Alkema, V. Kantorova, C. Menozzi, and A. Biddlecom, "National, regional, and global rates and trends in contraceptive prevalence and unmet need for family planning between 1990 and 2015: A systematic and comprehensive analysis," Lancet, vol. 381, pp. 1642-1652, 2013.Available at: https://doi.org/10.1016/s0140-6736(12)62204-1.

[3] World Health Organization, Safe abortion: Technical and policy guidance for health systems, 2nd ed. Geneva, Switzerland. Available from http://apps.who.int/iris/bitstream/10665/70914/1/9789241548434_eng.pdf, 2015.

[4] K. K. Nielsen, S. M. Nielsen, R. Butler, and J. V. Lazarus, "Key barriers to the use of modern contraceptives among women in Albania: A qualitative study," Reproductive Health Matters, vol. 20, pp. 158-165, 2012.Available at: https://doi.org/10.1016/s0968$8080(12) 40681-4$.

[5] K. K. Adjei, A. K. Laar, C. T. Narh, M. A. Abdulai, S. Newton, S. Owusu-Agyei, and S. Adjei, "A comparative study on the availability of modern contraceptives in public and private health facilities in a peri-urban community in Ghana," Reproductive Health, vol. 12, p. 68, 2015.Available at: 10.1186/s12978-015-0058-z.

[6] J. F. Levesque, M. F. Harris, and G. Russel, "Patient-centred access to health care: Conceptualising access at the interface of health systems and populations," International Journal for Equity in Health, vol. 12, p. 18, 2013.Available at: https://doi.org/10.1186/14759276-12-18.

[7] F. Landini, V. G. Cowes, and E. D’Amore, "Towards a theoretical framework for rethinking cultural accessibility," Cadernos de Saúde Pública, vol. 30, pp. 231-244, 2014.

[8] R. Penchansky and W. J. Thomas, "The concept of access: Definition and relationship to consumer satisfaction," Medical Care, vol. 19, pp. 127-140, 1981.Available at: https://doi.org/10.1097/00005650-198102000-00001.

[9] O. O'Donnell, "Access to health care in developing countries: Breaking down demand side barriers," Cadernos de Saúde Pública, vol. 23, pp. 2820-2834, 2007.Available at: https://doi.org/10.1590/s0102-311x2007001200003.

[10] J. C. Fortney, J. F. Burgess, H. B. Bosworth, B. M. Booth, and P. J. Kaboli, "A re-conceptualization of access for 21 st century healthcare," Journal of General Internal Medicine, vol. 26, pp. 639-647, 2011.

[11] C. Travassos and M. Martins, "A review on the concepts of access and use of health services," Cadernos de Saúde Pública, vol. 20, pp. s 190-s 198, 2004.Available at: https://doi.org/10.1590/s0102-311 x2004000800014.

[12] J. R. C. M. Ayres, "Organization of health care actions: Models and practices," Health and Society, vol. 18, pp. 21-23, 2009.Available at: https://doi.org/10.1590/s0104-12902009010600001.

[13] L. C. O. Cecílio, "Choices to innovate in the production of care, practices and knowledge: How can we not do more of the same?," Health and Society, vol. 21 , pp. 280-289, 2012.Available at: https://doi.org/10.1590/s0104-12902012000200003.

[14] R. Campbell, P. Pound, M. Morgan, G. Daker-White, N. Britten, R. Pill, L. Yardley, C. Pope, and J. Donovan, "Evaluating metaethnography: Systematic analysis and synthesis of qualitative research," Health Technology Assessment, vol. 15, pp. 1-164, 2011.Available at: https://doi.org/10.3310/hta15430.

[15] G. W. Noblit and R. D. Hare, Meta-ethnography: Synthesizing qualitative studies. Newbury Park, CA. London: Sage, 1988.

[16] A. Tong, P. Sainsbury, and J. Craig, "Consolidated criteria for reporting qualitative research (COREQ): A 32-item checklist for interviews and focus groups," International Journal of Quality in Health Care, vol. 19, pp. 349-357, 2007.Available at: https://doi.org/10.1093/intqhe/mzmo42.

[17] M. S. Correa, K. V. Feliciano, E. N. Pedrosa, and A. I. Souza, "Women's perception concerning health care in the post-partum period: A meta-synthesis," Open Journal of Obstetrics and Gynecology, vol. 4, pp. 416-426, 2014.Available at: https://doi.org/10.4236/ojog.2014.47062.

[18] P. Ay, S. Hidiroglu, A. Topuzoglu, M. S. Ucar, O. O. Kose, and D. Save, "Do perceived health risks outweigh the benefits of modern contraceptives? A qualitative study in a suburban population in Istanbul, Turkey," European Society of Contraception and Reproductive Health Care, vol. 12, pp. 154-161, 2007.Available at: https://doi.org/10.1080/13625180701300822.

[19] I. A. Khalaf, F. Abu-Moghli, L. C. Callister, and R. Rasheed, "Jordanian women's experiences with the use of traditional family planning," Health Care for Women International, vol. 29, pp. 527-538, 2008.Available at: https://doi.org/10.1080/07399330801949632.

[20] S. Mohammad-Alizadeh, R. Wahlström, R. Vahidi, and A. Johanssond, "A women's perceptions of quality of family planning services in Tabriz, Iran," Reproductive Health Matters, vol. 17, pp. 171-180, 2009.

[21] F. Majlessi, B. L. Moghaddam, and M. Shariat, "Client and health workers perceptions on family planning services," Iranian Red Crescent Medical Journal, vol. 13, pp. 469-474, 2011.

[22] A. Dennis and D. Grossman, "Barriers to contraception and interest in over-the-counter access among low-income women: A qualitative study," Perspectives on Sexual and Reproductive Health, vol. 44, pp. 84-91, 2012.Available at: https://doi.org/10.1363/4408412.

[23] S. Kohan, M. Simbar, and F. Taleghani, "Empowerment in family planning as viewed by Iranian women: A qualitative study," Journal of Biosocial Science, vol. 44, pp. 209-22 19, 2012.Available at: https://doi.org/10.1017/s0021932011000563.

[24] A. Khan and B. T. Shaikh, "An all time low utilization of intrauterine contraceptive device as a birth spacing method: A qualitative descriptive study in district Rawalpindi, Pakistan," Reproductive Health, vol. 10, p. 10, 2013.Available at: https://doi.org/10.1 186/1742-4755-10-10.

[25] E. J. Hodgson, C. Collier, L. Hayes, L. A. Curry, and L. Fraenkel, "Family planning and contraceptive decision-making by economically disadvantaged, African-American women," Contraception, vol. 88, pp. 289-296, 2013.Available at: https://doi.org/10.1016/j.contraception.2012.10.011.

[26] S. Kennedy, M. Grewal, E. M. Roberts, J. Steinauer, and C. Dehlendorf, "A qualitative study of pregnancy intention and the use of contraception among homeless women with children," Journal of Health Care for the Poor and Underserved, vol. 25, pp. 757-770, 2014.Available at: https://doi.org/10.1353/hpu.2014.0079.

[27] M. Sandelowski and J. Barroso, Handbook for synthesizing qualitative research. New York: Springer Publishing Company, 2007.

[28] S. Atkins, S. Lewin, H. Smith, M. Engel, A. Fretheim, and J. Volmink, "Conducting a meta-ethnography of qualitative literature: Lessons learnt," BMC Medical Research Methodology, vol. 8, p. 21, 2008.Available at: https://doi.org/10.1186/1471-2288-8-2 1.

[29] N. Britten, R. Campbell, C. Pope, J. Donovan, M. Morgan, and R. Pill, "Using meta-ethnography to synthesise qualitative research: A worked example," Journal of Health Services Research \& Policy, vol. 7, pp. 209-215, 2002.Available at: https://doi.org/10.1258/135581902320432732.

[30] F. Toye, K. Seers, N. Allcock, M. Briggs, E. Carr, and K. Barker, "Meta-ethnography 25 years on: Challenges and insights for synthesising a large number of qualitative studies," BMC Medical Research Methodology, vol. 14, p. 80, 2014.Available at: https://doi.org/10.1186/1471-2288-14-80.

[31] E. H. Bradley, L. A. Curry, and K. J. Devers, "Qualitative data analysis for health services research: Developing taxonomy, themes, and theory," Health Services Research, vol. 42, pp. 1758-1772, 2007.Available at: https://doi.org/10.1111/j.1475-6773.2006.00684.x.

[32] D. B. Farmer, L. Berman, G. Ryan, L. Habumugisha, P. Basinga, C. Nutt, F. Kamali, E. Ngizwenayo, J. St Fleur, P. Niyigena, F. Ngabo, P. E. Farmer, and M. L. Rich, "Motivations and constraints to family planning: A qualitative study in Rwanda's Southern Kayonza district," Global Health: Science and Practice, vol. 3, pp. 242-254, 2015.Available at: https://doi.org/10.9745/ghsp-d-14oo 198.

[33] G. Mustafa, S. K. Azmart, W. Hameed, S. Ali, M. Ishaque, W. Hussain, A. Ahmed, and E. Munroe, "Family planning knowledge, attitudes, and practices among married men and women in rural areas of Pakistan: Findings from a qualitative need assessment study," International Journal of Reproductive Medicine, vol. 2015, p. 8, 2015.Available at: http://dx.doi.org/10.1155/2015/190520. 
[34] A. Kabagenyi, L. Jennings, A. Reid, G. Nalwadda, J. Ntozi, and L. Atuyambe, "Barriers to male involvement in contraceptive uptake and reproductive health services: A qualitative study of men and women's perceptions in two rural districts in Uganda," Reproductive Health, vol. 11, p. 21, 2014.Available at: https://doi.org/10.1186/1742-4755-11-21.

[35] G. Nanda, S. R. Schuler, and R. Lenzi, "The influence of gender attitudes on contraceptive use in Tanzania: New evidence using husbands' and wives' survey data," Journal of Biosocial Science, vol. 45, pp. 331-344, 2013.Available at: https://doi.org/10.1017/s0021932012000855.

[36] M. Kassa, A. A. Abajobir, and M. Gedefaw, "Level of male involvement and associated factors in family planning services utilization among married men in Debremarkos town./ Northwest Ethiopia," BMC International Health and Human Rights, vol. 14, p. 33, 2014.Available at: https://doi.org/10.1186/s12914-014-0033-8.

[37] R. Ochako, M. Mbondo, S. Aloo, S. Kaimenyi, R. Thompson, M. Temmerman, and M. Kays, "Barriers to modern contraceptive methods uptake among young women in Kenya: A qualitative study," BMC Public Health, vol. 15, p. 118, 2015.Available at: https://doi.org/10.1186/s12889-015-1483-1.

[38] M. J. Hindin, L. J. Mc Gough, and R. M. Adanu, "Misperceptions, misinformation and myths about modern contraceptive use in Ghana," Journal of Family Planning and Reproductive Health Care, vol. 40, pp. 30-35, 2014.Available at: https://doi.org/10.1136/jfprhc-2012-100464.

[39] M. Claramita, M. D. F. Nugraheni, V. J. Dalen, and V. D. C. Vleuten, "Doctor-patient communication in Southeast Asia: A different culture?," Advances in Health Sciences Education, vol. 18, pp. 15-31, 2013.Available at: https://doi.org/10.1007/s10459012-9352-5.

[40] A. M. Gomez, L. Fuentes, and A. Allina, "Women or LARC first? Reproductive autonomy and the promotion of long-acting reversible contraceptive methods," Perspectives on Sexual and Reproductive Health, vol. 46, pp. 171-175, 2014.Available at: https://doi.org/10.1363/46e1614.

[41] E. Verlinde, N. Laender, S. Maesschalck, M. Deveugele, and S. Willem, "The social gradient in doctor-patient communication," International Journal for Equity in Health, vol. 11, p. 12, 2012.Available at: 10.1186/1475-9276-11-12.

[42] S. Pachauri, "Priority strategies for India's family planning programme," Indian Journal of Medical Research, vol. 140, pp. s137-s 146, 2014.

[43] S. Garg and R. Singh, "Need for integration of gender equity in family planning services," Indian Journal of Medical Research, vol. 140, pp. s 147-s51, 2014. 